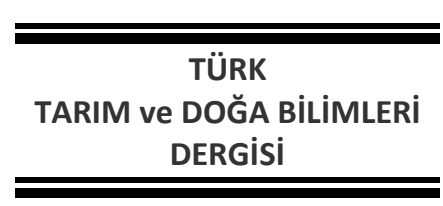

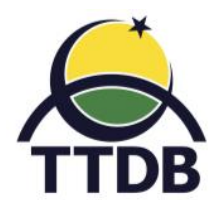

www.dergipark.gov.tr/turkjans

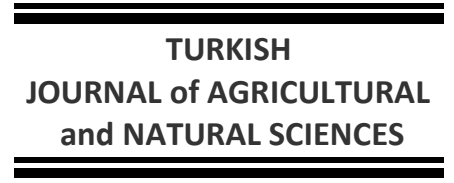

Araştırma Makalesi

\title{
Asma Fidanı Üretim Parselinde Solarizasyon Uygulaması Öncesi ve Sonrası Toprak Mikrofunguslarının Belirlenmesi
}

\author{
Nurdan GÜNGÖR SAVAŞ ${ }^{1 *}$, Davut Soner AKGÜL ${ }^{2}$, Esra ALBAZ ${ }^{1}$, Yüksel SAVAŞ ${ }^{1}$ \\ ${ }^{1}$ Manisa Bağcılık Araştırma Enstitüsü, 45125, Manisa, \\ ${ }^{2}$ Çukurova Üniversitesi Ziraat Fakültesi, Bitki Koruma Bölümü, Balcalı, Adana \\ *Sorumlu yazar: nurdan.gungorsavas@tarim.gov.tr
}

\author{
Geliş Tarihi: 08.01.2018
}

Düzeltme Geliş Tarihi: 12.07.2018

Kabul Tarihi: 16.07.2018

\section{Özet}

Bu çalışma, asma fidanı üretim parseli toprağında solarizasyon öncesi ve sonrası mikrofungusların belirlenmesi amacıyla, Manisa Bağcılık Araştırma Enstitüsü Müdürlüğü fidanlık parselinin $500 \mathrm{~m}^{2}{ }^{\prime} l i k$ alanında 2014 yılında yürütülmüştür. Solarizasyon uygulaması öncesi toprağı seyreltme yöntemi ile gerçekleştirilen izolasyon sonrasında; asma fidanlığı toprağının bir gramında $99 \times 10^{3}$ koloni oluşturan birim (KOB) mikrofungus bulunduğu, bunların Ascomycota bölümüne ait 10 cins içerdiği belirlenmiştir. Çalışmada tespit edilen fungus cinsleri, alfabetik sıraya göre; Acremonium, Alternaria, Aspergillus, Cylindrocarpon, Epicoccum, Fusarium, Mortierella, Mucor, Myrothecium, Penicillium, Rhizopus ve Trichoderma olduğu tespit edilmiştir. Tür zenginliği bakımından ele alındığında; Fusarium, Aspergillus, Trichoderma, Penicillium, Acremonium cinslerinin öne çıktığı belirlenmiştir. Araştırma, koloni sayıları bakımından değerlendirildiğinde Fusarium cinsinin ilk sırayı aldığı, bunu Aspergillus, Epicoccum, Penicillium ve Acremonium cinslerinin izlediği anlaşılmıştır. Buna göre, gerek tür zenginliği ve gerekse koloni sayısı bakımından, Fusarium cinsinin ilk sırayı aldığı tespit edilmiştir. Çalışmanın diğer aşamasında, temmuz-ağustos aylarında, $0.125 \mathrm{~mm}$ kalınlığında şeffaf polietilen örtü kullanılarak 8 hafta süreyle solarizasyon uygulaması yapılmıştır. Solarizasyon uygulaması sonrası parselde toprağı seyreltme yöntemi ile izolasyon çalışmaları tekrarlanmıştır. İzolasyon sonrası en yaygın cinslerin ise sırasıyla, Trichoderma, Penicillium, Aspergillus ve Alternaria olduğu belirlenmiştir. Asma fidanlık topraklarında solarizasyon uygulaması sonrası mikrofungal türlerin ve çeşitliliğinin azaldığı belirlenmiştir. Çalışma bulgularının, toprak fungusları üzerine abiyotik faktörlerin etkisinin değerlendirilmesine yönelik çalışmalara katkı oluşturacağı kanısındayız.

Anahtar kelimeler: Asma fidanlığı, toprak mikrofungusları, solarizasyon.

\section{Determination of Soil Microfungi in Grapevine Sapling Production Parcel Before and After the Application of Solarization}

\begin{abstract}
It was carried out in the area of $500 \mathrm{~m}^{2}$ of the nursery parcel of Manisa Viticulture Research Institute for the purpose of determination of soil microfungi in grapevine nursery production parcel before and after the application of solarisation. It was determined that after isolation, done by soil dilution method before the application of solarisation, there was $99 \times 10^{3}$ colony forming unit (CFU) microfungi per a gram of grapevine soil and these contain in 10 genera that belong to the fungal divisions of Ascomycota. The fungi taxa determined in the study, according to the order of alphabetic, are as follows; Acremonium, Alternaria, Aspergillus, Cylindrocarpon, Epicoccum, Fusarium, Mortierella, Mucor, Myrothecium, Penicillium, Rhizopus and Trichoderma. When considered in terms of species richness, it was identified that Fusarium, Aspergillus, Trichoderma, Penicillium, Acremonium prominent. When the study is evaluated in terms of colony numbers, it is understood that Fusarium genera first and it is followed by Aspergillus, Epicoccum, Penicillium and Acremonium. According to this, it has been concluded that in terms of both species richness and number of colonies, Fusarium is in the first place. In the other phase of the work, solarisation was applied for 8 weeks in July-August using a transparent polyethylene
\end{abstract}


cover with a thickness of $0.125 \mathrm{~mm}$. After solarisation application, isolation was repeated with soil dilution method in the parcel. After isolation, it was determined that the most common genera were, respectively, Trichoderma, Penicillium, Aspergillus and Alternaria. It has been determined that the microfungal taxa and genera grapevine nursery soils decreased after solarisation application. We believe that the findings of the study will contribute to the evaluation of the effect of abiotic factors on soil fungi.

Key words: Grapevine nursery, soil microfungi, solarization.

\section{Giriş}

Toprak fungusları; doğal ve işlenmiş topraklarda, organik maddenin ayrıştırılması, metabolitlerin kimyasal yapısını değiştirme, iz elementlerin oluşumu ve toprak strüktürünün iyileştirilmesi gibi ekosistem süreçlerinde öneme sahiptirler. Ayrıca, toprak kaynaklı bitki hastalıklarının kontrol edilmesinde ve bitki gelişiminin teşvik edilmesinde rol alırlar (Garbeva ve ark., 2004).

Fidanlıklarda görülen toprak kaynaklı bazı funguslar önemli kayıplara neden olurlarken epidemi kaynağı da oluşturmaktadırlar. Çeşitli hastalık etmeni ve zararlıların gerek doğrudan fidan üretimini etkilemesi gerekse yeni tesis edilen temiz plantasyonlara taşınması bitki koruma açısından önemlidir (Fidan ve Yavaş, 1987).

2010 yılında 11 ilde toplam 4,2 milyon asma fidanı üretilmiştir. Manisa ili üretimin \%66.5'ini gerçekleştirirken Denizli \%9.5; Adıyaman \%7.6; Şanlıurfa \%5.5 ve Bilecik \%5.4 üretim oranları ile diğer önemli asma fidanı üreten illerdir (Savaş ve ark., 2013). Sertifikalı olarak üretilecek fidanlarda iç ve dış karantina etmenleri yönünden bir dizi analiz yapılır. Bu asma fidanları Phaeoacremonium spp., Stereum hirsitum, Phellinus igniarius, Cylindrocarpon spp., Phomopsis viticola, Eutypa lata fungusları yönünden incelenmektedir (Anonim, 2016). Bu funguslardan Cylindrocarpon spp. toprak kaynaklı olup, fidanlıklarda ve yeni tesis edilen bağlarda verim ve ekonomik kayıplara neden olmaktadır (Halleen ve ark., 2006).

Toprak kaynaklı patojenleri içeren çalışmalar incelendiğinde; Phytophthora ve Phythium genusuna ait türler asma fidanlıklarında fidanların kök ve kök boğazı bölgesindeki alanlardan izole edilirken, ayrıca Macrophomina phaseolina, Rhizoctonia solani gibi patojenler de saptanmıştır (Marais, 1979). Konukçu bitki olmadan da uzun yıllar toprakta yaşayabilen, Armillaria spp., Fusarium spp., Plasmodiophora spp., Sclerotium spp. ve Verticillium spp. gibi bitki patojenleri toprak kökenlidir. Cylindrocarpon spp. en yaygın bilinen saprofit özellikteki toprak kaynaklı ve asma fidanlarının yararlanan kökleri üzerine yerleşerek iletim sisteminde gelişen önemli bir patojendir. Klamidosporları ile uzun süre toprakta yaşamını devam ettirmektedir (Halleen ve ark., 2006). Myrothecium roridum bir toprak patojenidir ve 200'den fazla bitki türünde yaprak lekesi, gövde kanseri ve meyve çürüklüğüne neden olmaktadır. Özellikle Brezilya, Belçika, Hindistan, Kanada'nın güneyi, İtalya gibi tropikal ve subtropikal iklim koşullarına sahip ülkelerden sıklıkla $M$. roridum izole edilmiştir (Quezado ve ark., 2010). Acremonium; bitki artıkları, besin maddeleri, çürümüş mantarlardan ve topraktan izole edilebilen yaygın ve fırsatçı fungal patojenlerden biridir. Bu fungus türünün optimum gelişimi için mutlaka yüksek miktarda neme ihtiyaç vardır ve $\beta$-laktam grubu cephalosporins isimli ticari antibiyotiklerin üretiminde kullanılmaktadır (Vega ve ark., 2008). Bazı türlerinin de bitkilerde hastalık yapan diğer fungus türleri üzerinde kontrol ajanı olarak denendiği bilinmektedir (Kiss, 2003). Alternaria alternata hem saprofitik hem de bitki patojeni bir türdür. Birçok bitkide "alternaria çürüğü", "alternaria yaprak yanıklığı veya lekesi” adı verilen hastalıklara neden olmaktadır. Alternaria alternata bağda salkım çürüklüğü patojenleri arasında yer almaktadır, önemli verim kayıplarına yol açan hasat sonrası hastalık etmenlerinden bir tanesidir (Savaş ve Yıldız, 2015).

Solarizasyon, şeffaf plastik örtü ile toprağın kapatılarak bir sera etkisi yaratılması ve solar radyasyon ile temizlenmesini sağlayan pasif bir hidrotermal süreçtir. Toprak solarizasyonu, 1970'lerin ortasında İsrail'de geliştirilmiştir, toksik etkiye neden olmadan yabancı ot tohumlarını, nematodları, birçok patojenii ve zararlıları etkili şekilde öldürebilen bir kontrol aracıdır (Katan ve DeVay, 1991).

Solarizasyon birçok zararlı ve hastalık etmeninin de içinde bulunduğu ılık koşularda gelişen zararlı organizmalara zarar verirken sıcak koşullarda gelişen funguslar ve Bacillus spp. üzerinde ise herhangi bir etkisinin olmadığı tespit edilmiştir (Stapleton ve DeVay, 1986). Birçok patojenin biyolojik mücadele ajanı olan Trichoderma spp. üzerine solarizasyonun olumsuz etkisinin olmadığı yapılan araştırmalar ile belirlenmiştir. Yapılan çalışmalarda solarizasyon uygulaması sonrası topraklar da patojenlerin daha çok baskılandığı belirtilmiştir. Örneğin, Fusarium oxysporum f. sp. vasinfectum'un topraktaki yoğunluğunun solarizasyon uygulaması sonrası üç yıl boyunca kontrol edildiği (Katan ve ark., 1983) ve toprağın ilk $12 \mathrm{~cm}$ derinliğinde bulunan Verticillium 
dahliae'nın varlığının engellendiği bildirilmiştir. Solarizasyonun kontrol mekanizmasının yalnızca ısı artışı ile dezenfeksiyon olmadığı ayrıca, bitki gelişimini ve faydalı mikroorganizma aktivitesini arttırdığı ortaya konulmuştur (Katan ve ark., 1983). Ben-Yelphet ve Shtienberg (1995) tarafından biyolojik mücadele ajanı Trichoderma spp. üzerine solarizasyonun olumsuz bir etkisinin olmadığı belirtilmiştir.

Bu çalışmada, asma fidanı üretim parselinde solarizasyon uygulaması öncesi ve sonrası toprak mikrofunguslarının belirlenmesi amaçlanmıştır. Toprak mikrofunguslarından asma fidanlığında patojen olabilme özelliğine sahip bazı türlerin tanılanmasında morfolojik tanılamanın yanında moleküler tanılama yöntemi de kullanılmıştır.

\section{Materyal ve Yöntem Materyal}

Manisa Bağcılık Araştırma Enstitüsü Müdürlüğü'ne ait fidan üretim arazisinin $500 \mathrm{~m}^{2 \prime}$ lik parseli ve 5 farklı noktadan alt örnekleme ile alınan toprak örnekleri, solarizasyon uygulamasında kullanılan $0.125 \mathrm{~mm}$ kalınlığında deliksiz, şeffaf plastik örtü materyalimizi oluşturmuştur.

\section{Yöntem}

\section{Arazi çalışmaları}

Çalışma kapsamında solarizasyon uygulaması öncesi ve sonrası toprak örneklerinin alındığı parsel Manisa Bağcılık Araştırma Enstitüsü Müdürlüğü'ne ait fidan üretim arazisinin $500 \mathrm{~m}^{2 \prime}$ lik parselinde zig zaglar çizilerek $0-30 \mathrm{~cm}$ derinliğinde 5 toprak örneği 5 tekerrürlü olarak toplamda 25 adet farklı noktadan toprak örneği alınmıştır. Yaklaşık 1.5 kg ağırlığındaki her bir toprak örneği polietilen poşetler içerisinde laboratuvara getirilmiştir.

Laboratuvara getirilen her bir toprak örneğinin yarısı, aynı gün içerisinde, fırın kuru ağılıklarının belirlemek ve kimyasal analiz işlemleri için Manisa Bağcılık Araştırma Enstitüsü toprak ve yaprak analiz laboratuvarına teslim edilmiştir. Kimyasal analiz kapsamında toprak örneklerinde $\mathrm{pH}$, tuzluluk, kireç, azot, fosfor, potasyum, sodyum, demir, bakır, çinko ve mangan değerleri belirlenmiştir. Diğer yarısı ise, toprağın mikrobiyal yapısının bozulmaması amacıyla mikrobiyal analiz gerçekleştirilene kadar +4 o ${ }^{\prime}$ ye ayarlı buzdolabında muhafaza edilmiştir.

Toprak örnekleri alındıktan sonra, çalışma parselinde solarizasyon uygulaması gerçekleştirilmiştir. 2014 yılı haziran ayında parsel 30-40 cm derinlikte işlenmiş ve keseksiz hale getirilmiştir. Solarizasyon uygulaması için $500 \mathrm{~m}^{2}$ parsel üzerine $50 \mathrm{~cm}$ aralıklar ile damlama boruları yerleştirilmiş, doyma noktasına ulaşıncaya kadar sulanmıştır. Toprak tava ulaşınca keseksiz düz bir yüzey oluşturulmuş, 0.125 mm kalınlığında deliksiz, şeffaf plastik örtü ile kapatılmıştır. Toprak ve örtü arasında, hava boşlukları oluşmamasına, solarizasyon örtüsünün gergin durmasına ve toprak yüzeyine değmesine dikkat edilmiştir. Solarizasyon parselinin çevresinde açılan 15-20 cm derinliğindeki karıklar içine örtü materyalinin kenarları iyice gömülmüştür. Toprak 2 haftada bir damlama sulama sistemi ile nemlendirilmiş ve 8 hafta süreyle (4 Temmuz- 29 Ağustos 2014 tarihleri arasında) solarizasyon uygulaması yapılmıştır. Solarizasyon örtüsü kaldırıldıktan 1 hafta sonra toprak örneği alma işlemleri gerçekleştirilmiş ve alınan örnekler mikrobiyolojik analizler yapılıncaya kadar +4 o C'ye ayarlı buzdolabında muhafaza edilmiştir.

\section{Laboratuvar Çalışmaları Topraktan fungusların izolasyonu}

Toprak örneklerinin mikrofungus yoğunluklarının belirlenmesi için örnekler toprağı seyreltme metodu (Waksmann, 1922) ile seyreltilerek analize hazır hale getirilmiştir. Bu yönteme göre, önceden yüzde nem miktarı belirlenen toprak numunelerinin her birinden ayrı ayrı 10 gr toprak örneği tartılmış ve üzerine $100 \mathrm{ml}$ steril saf su ilave edilmiştir. Stok solüsyon homojenizasyonu sağlamak için iyice karıştırılmış ve daha sonra bu solüsyon kullanılarak $10^{-2}-10^{-6}$ lık dilüsyonlar hazırlanmıştır. Bu süspansiyonlardan steril pipetle $1 \mathrm{ml}$ örnek alınarak, içerisine streptomycin ilave edilmiş Patates Dekstroz Agar (PDA) içeren petrilere inoküle edilmiştir. Daha sonra petri kutularının çevresi parafilm ile sarılmıştır. Çalışma, her bir toprak örneği için 5 tekerrürlü olarak yürütülmüştür. Petriler, $25^{\circ} \mathrm{C}^{\prime}$ ye ayarlanmış, 12 saat aydınlatmalı inkübatöre yerleştirilerek, 7 gün inkübe edilmiştir.

Petrilerde gelişen fungal kolonilerin sayımı inkübasyon periyodu sonunda yapılmış ve toprak örneklerindeki koloni oluşturan birim (KOB, canlı hücre sayısı) aşağıdaki formülle hesaplanmıştır (Christensen, 1981). toprakta)

$S=\operatorname{axbx100/(100-N)}$

S: Toplam fungus sayısı (1 gramlık fırın kuru

a: Petri kaplarında bulunan ortalama koloni oluşturan birim sayısı

b: Seyreltme faktörünü

N: Toprak örneğine ait yüzde nem miktarı

\section{Izolatların tanılanması ve saflaştırılması}

Sayımın ardından petride gelişen fungal koloniler fluorescence mikroskop (Olympus BX51) altında incelenmiştir. Fungal koloniler, PDA içeren eğik agar tüplerine aktarılarak saflaştırılmıştır. Her bir izolatın, petri kabındaki koloni (tekerrür) sayısı 
kaydedilmiştir. İzolatlar, $25{ }^{\circ} \mathrm{C}^{\prime}$ ye ayarlı, 12 saat aydınlatmalı inkübatörde 7 gün inkübe edilmiştir ve gelişen koloniler morfolojik özelliklerine göre sınıflandırılarak morfotiplere ayrılmıştır. Bu morfotipleri temsil etmesi amacı ile bir izolat seçilmiş ve teşhis için PDA besi ortamına aktarılmıştır. Özellikle Mucorales takımına ve Ascomycota sınıfı üyesi Penicillium ile Aspergillus cinslerine ait izolatlar, malt ekstrakt agar (MEA) besi yerine aktarılarak geliştirilmişlerdir. Teşhis çalışmalarında, saflaştırılan morfotip izolatlarının 24-25 ${ }^{\circ} \mathrm{C}$ 'ye ayarlı, 12 saat aydınlatmalı inkübatörde 6-7 gün inkübe edilmiş kültürleri kullanılmıştır ve stok kültürleri içeren tüpler $+4{ }^{\circ} \mathrm{C}^{\prime}$ de muhafaza edilmiştir.

Fungusların tanısı, saflaştırılan izolatların koloni morfolojileri ve üretken yapı özelliklerine göre yapılmıştır. Her bir izolattan hazırlanan preparatlar, 20-40-100 büyütmeli mikroskop altında saf su ve immersiyon yağı kullanılarak incelenmiştir. Fungus tanısında çeşitli temel mikolojik yayınlardan (Burgess ve ark., 1994; Pitt, 2000; Kirk ve ark., 2001; Klich, 2002; Samson ve ark., 2004) faydalanılmıştır. Ayrıca, taksonomik tanılamada "www.indexfungorum.org" sitesinden yararlanılmıştır.

Araştırma parseli toprağından izole edilen mikroskobik funguslar cins ve tür seviyesinde teşhis edilmiştir. Kantitatif değerlendirmelerde, izolasyon ortamında fungusların oluşturdukları koloni sayıları belirlenmiştir. Daha sonra, tanısı yapılan fungusların bulunma sıklığı (\%) her bir fungusun toplam koloni sayısına bölünmesi ile belirlenmiştir.

\section{DNA izolasyonu ve PCR amplifikasyonları}

Elde edilen mikrofungal türlerden asma fidanlığında patojen olma olasılığı düşünülen türler için moleküler tanılama aşamasında Fungal DNA, Cenis (1992)'in ekstraksiyon protokolü izlenmiştir. DNA izolasyonu ve PCR amplifikasyonları ile morfolojik olarak tanılaması yapılan mikrofungal türlerin moleküler düzeyde tanılamaları da gerçekleştirilmiştir. Bu amaçla, izolatların taze kültürlerinden, steril bir bistürü ile yaklaşık $50 \mathrm{mg}$ misel alınarak, üzerine $550 \mu \mathrm{l}$
DNA ekstraksiyon tamponu (200 mM Tris- $\mathrm{HCl}, 250$ $\mathrm{mM} \mathrm{NaCl}, 25 \mathrm{mM}$ EDTA ve \%2 Sodium Dodecyl Sulphate) eklendikten sonra homojenize edilmiş ve elde edilen ekstraksiyon 1,5 ml'lik steril mikrosantrifüj tüplerine aktarılmıştır. Homojenizasyondan sonra, tüplere $150 \mu \mathrm{l} 3 \mathrm{M}$ Sodyum Asetat (NaOAc) ilave edilmiş ve 15 dakika boyunca $-20^{\circ} \mathrm{C}$ de inkübe edilmiştir. Homojenatlar 14.000 rpm'de 10 dakika santrifüj edilmiş ve süpernatantlar $(200 \mu l)$ yeni mikrosantrifüj tüplerine aktarılmıştır. Süpernatantların üzerine eşit hacimde izopropanol (2-propanol) ilave edilmiş ve yavaş bir şekilde yaklaşık beş kez karıştırıldıktan sonra tüpler $0{ }^{\circ} \mathrm{C}^{\prime}$ de 10 dakika inkübe edilmiştir. Daha sonra DNA peleti, 14.000 rpm'de 10 dakika boyunca santrifüj edilerek çöktürülmüş ve süpernatant atılmıştır. DNA 1-2 saniye boyunca $1 \mathrm{ml}$ $\% 70$ etanol ile yıkanmış ve tüpler 10 dakika kurutma kâğıdı üzerinde ters bekletilerek peletin kuruması sağlanmıştır. Son olarak DNA, $75 \mu \mathrm{TE}$ (1M Tris- $\mathrm{HCl}$, ve 0.5 M EDTA) tamponuyla asılı hale getirilerek ve $20^{\circ} \mathrm{C}^{\prime}$ de saklanmıştır. İzole edilen DNA'nın konsantrasyonu ve saflığı, Multiscan GO $\mu$-drop plate (Thermo Scientific, ABD) ile belirlenmiştir.

İzolatların moleküler tanılanması, fungusların korunmuş farklı gen bölgesine spesifik olarak gerçekleştirilmiş PCR ampilifikasyonu ile yapılmıştır. Bu amaçla, ITS (White ve ark., 1990) gen bölgesine ait Çizelge 1'de verilen bir adet primer çifti kullanılmıştır. PCR reaksiyonları, steril PCR tüpleri içerisine $0,3 \mu \mathrm{l} 20$ $\mu \mathrm{M}$ forward primer, 0,3 $\mu \mathrm{l} 20 \mu \mathrm{M}$ reverse primer, $2 \mu \mathrm{l}$ DNA ve $10 \mu \mathrm{l}$ 2x FastStart Essential DNA Green Master Mix eklenerek DNase/RNase ari su ile son hacim 20 $\mu$ l'ye tamamlanarak gerçekleştirilmiştir. Her koşumda 1 tüp olası kontaminasyon riskine karşı örnek eklenmeden negatif kontrol olarak çalışmaya eklenmiştir. ITS'e ait sekanslar ve Real-Time PCR döngüleri Çizelge 1'de yer almaktadır. PCR amplifikasyonundan sonra gerçekleştirilecek melting analizi ile primer dimerleri gibi spesifik olmayan amplifikasyonlar bertaraf edilerek çoğaltılan bölgenin hedef bölge olup olmadığı belirlenmiştir. Her fungusa özgü PCR ürünü sekans analizi yapan Macrogen Europe (www.macrogen.com) biyoteknoloji firmasında baz dizileri belirlenmiştir.

Çizelge 1. Çalışmada primer, sekansı ve primere ait gen bölgesinin amplifikasyonu için Real-Time PCR döngüsü.

\begin{tabular}{ccccc}
\hline $\begin{array}{c}\text { Gen } \\
\text { Bölgesi }\end{array}$ & $\begin{array}{c}\text { Primer Adı } \\
\text { (forward/reverse) }\end{array}$ & Primer sekansı (5'- $\mathbf{3}^{\prime}$ ) & $\begin{array}{c}\text { Amplikon } \\
\text { büyüklüğü } \\
\text { (bp) }\end{array}$ & Real-Time PCR döngüleri \\
\hline & ITS 4 & TCC TCC GCT TAT TGA TAT GC & & $94^{\circ} \mathrm{C}: 3 \mathrm{dk}$. \\
ITS & ITS 5 & GGA AGT AAA AGT CGT AAC AAG G & 580 & $\begin{array}{c}\left(95^{\circ} \mathrm{C}: 20 \mathrm{sn} ., 51^{\circ} \mathrm{C}: 10\right. \\
\text { sn., } 72^{\circ} \mathrm{C}: 1 \mathrm{dk} \text {.) X } 35 \\
\text { döngü }\end{array}$ \\
\hline
\end{tabular}


Bulgular ve Tartışma

\section{Araştırma parseli toprağında bulunan mikrofungus sayıları}

Solarizasyon öncesi asma fidanı parselinden alınan toprak örneklerinde mikrofungal flora incelendiğinde en düşük ortalama $37.000 \mathrm{KOB} \mathrm{g}^{-1}$ ve en yüksek ortalama $74.667 \mathrm{KOB}^{-1}$ değerleri arasında olmak üzere, ortalama 46.533 birim mikrofungus tespit edilmiştir.

Blastik konidiumlar ile üreyebilen Aspergillus ve Penicillium gibi funguslar, bir hifin ucundan yada ana hücreden köken alıp çok geniş alanlara yayılabilirler, izolasyon sırasında petri ortamında gelişen fungal kolonilerin tek spor ya da hif parçasından gelişip gelişmediği anlaşılamamaktadır. Çalışmada belirlenen koloni sayısı, fidanlık parseli toprağında çok sayıda hif parçası ya da farklı üreme yapılarından oluşmuş spor kitlesinin dağılımını da gösterebilir (Hasenekoğlu, 1982). Bu konuda orman topraklarında yapılan araştırmalara ait sayım sonuçları incelendiğinde (Hasenekoğlu ve Azaz, 1991; Kara, 2002), genellikle 1 gram verimli toprakta kabul edilebilir mikrofungi sayısını yaklaşık 400.000 KOB $\mathrm{g}^{-1}$ olarak bildirdiğinden, asma fidanı parseli toprağındaki, $46.533 \mathrm{KOB} \mathrm{g}^{-1}$ mikrofungi sayısı ile kalitatif yönden fakir olduğu söylenebilir. Tarım yapılan alanlarda toprakta kabul edilebilir mikrofungi sayısının düşük yada yüksek olmasının sebebi, başta sıcaklık farkı olmak üzere ekimi yapılan ürünler ve kimyasal mücadelede kullanılan farklı pestisitler ile gübreleme miktarları ve sulama olabilir (Kalyoncu ve Özer, 2017).

Solarizasyon öncesi asma fidanlığı parseline ait toprağın mikrofungus florasını incelemek amacıyla yapılan izolasyonlar sonucunda, 145 izolat elde edilmiştir. Tanısı yapılan izolatların 10 cinse ait olduğu belirlenmiştir (Çizelge 2).

Çizelge 2'de, asma fidanlığı parselinde solarizasyon öncesi toprağında, Ascomycota bölümüne ait 10 cins fungus içerdiği belirlenmiştir. Bu cinslerden, 7'si Ascomycota bölümünde, 3'i ise Mucoromycota bölümünde yer almaktadır. Ascomycota bölümüne dâhil cinslerin tamamının, Peziziomycotina alt bölümünde yer aldığı belirlenmiştir. Ayrıca, Mucoromycota bölümüne ait Mortierellomycotina (1 cins) ve Mucoromycotina (2 cins) alt bölümünde yer alan cinslerde saptanmıştır.

Çizelge 2 incelendiğinde, bu çalışmada tespit edilen funguslar içinde tür ve bulunma sıklığı bakımından Fusarium cinsinin ilk sırayı aldığı anlaşılmaktadır. Askomycota bölümüne dahil olan Fusarium cinsi funguslar, $32\left(\times 10^{3}\right)$ koloni ile frekans, 5 tür ile çeşitlilik bakımından en fazla izole edilen fungal grup olmuştur. Toplam funguslar içerisinde Fusarium türlerinin \%32.32 oranında bir paya sahip olduğu saptanmıştır (Çizelge 2). Fusarium spp.'nin tarım topraklarında baskın mikrofungus olmasının, aralıksız devam eden ürün yetiştiriciliği sonucu olarak toprakta kalan bitki artıklarında populasyonlarını arttırdığı düşünülmektedir. Yapılan çalışmalarda narenciye bahçesi ile buğday tarlasına ait topraklarda dominant mikrofungus olduğu ve en yaygın türlerin ise $F$. oxysporum ve $F$. graminearum Group 1 türleri olduğu tespit edilmiştir (Leslie ve ark., 1990). Fusarium'un bazı türleri toprak patojeni olup fidelik ve fidanlıklarda çökerten hastalığına neden olmakta ve önemli kayıplar oluşturmaktadır. Fusarium solani patojenik bir fungus olup bitkilerde kök çürüklüğü hastalığına neden olmaktadır (Elad ve Baker, 1985). Çalışmamızda F. solani türü izole edilmiştir. Asma fidanlığı toprağında bu türün patojen olma olasılığının yüksek olduğu düşünülmektedir.

Çalışmada elde edilen Aspergillus cinsine ait türler; $A$. niger, A. flavus, $A$. parasiticus ve $A$. fumigatus olduğu tespit edilmiştir. Bazı orkide türlerinde farklı yöntemlerle izole edilen fungusların tespit edildiği çalışmada, orkide topraklarından dökme plak yöntemi ile yoğun olarak Fusarium ve Aspergillus fungusları izole edilirken; Rhizoctonia, Verticillium ve Trichoderma fungusları daha az sayıda elde edilmiştir. Orkide türleri açısından, seyreltme oranlarının izole edilen funguslar üzerinde çok farklılık göstermediği tespit edilmiştir (Çığ ve Yılmaz, 2004).

Araştırma parseli toprağının mikrofungal flora içerisinde Penicillium cinsi fungusların, 3 tür içerdiği ayrıca toplam fungusların \%13.13'ünü oluşturduğu ve 3. sırada yer aldığı anlaşılmaktadır (Çizelge 2). Türkiye'de ve dünyadaki araştırmalar incelendiğinde Penicillium cinsine ait türlerin araştırma alanı topraklarının baskın mikoflorasını oluşturması, ortak sonuçlardan bir tanesidir (Azaz ve Hasenekoğlu, 1997; Azaz ve Pekel, 2002; Kara, 2002). Christensen ve ark. (2000) tarafından farklı yetişme ortamlarındaki topraklarda bulunan funguslarla ilgili araştırmalar karşılaştırılmış ve genelde ortalama 90 fungus türü bulunduğunu ve bunların \%21'ini Penicillium cinsine ait türlerden oluştuğu tespit edilmiştir. Buna göre, çalışma alanından izole edilen 22 türün 3'ünü Penicillium cinsine bağlı türlerin oluşturduğu belirlenmiştir.

Solarizasyon öncesi izolasyonlarda elde edilen bazı funguslarda antogonistik ve patojen etikiye sahip olduğu düşünülen türler bulunmuştur (Çizelge 2). Cylindrocarpon macrodidymum tüm izolatlar içerisinde \%1.02'sini oluşturmaktadır. Cylindrocarpon spp.'leri Karabacak hastalığı etmenleri olarak tanımlanmakta hem bağ alanlarında odun doku kanserlerine hem de fidanlarda kurumalara neden olan önemli bağ hastalıkları içerisinde yer almaktadır (Petit ve Gubler, 2006). Dünya genelinde tüm bağ alanlarında bulunan, yeniden dikim maliyetlerini arttıran, 
ürünün miktarında ve kalitesinde azalmaya, önemli ekonomik kayıplara neden olan çok tahripkâr bir hastalıktır (Úrbez-Torres ve ark., 2006). Myrothecium roridum tüm izolatlar içerisinde \%2.02'lik bir orana sahiptir. Bu türünde toprak patojeni olma ihtimali bulunmaktadır, bitkilerde köklerde ve dallarında nekrozlara neden olmaktadır (Rai ve Mamatha, 2005).

Çizelge 2. Solarizasyon öncesi ve sonrası fidan parselinden alınan toprak örneklerinden izole edilen fungus cins ve türleri, koloni sayısı, tüm funguslar içerisindeki payı.

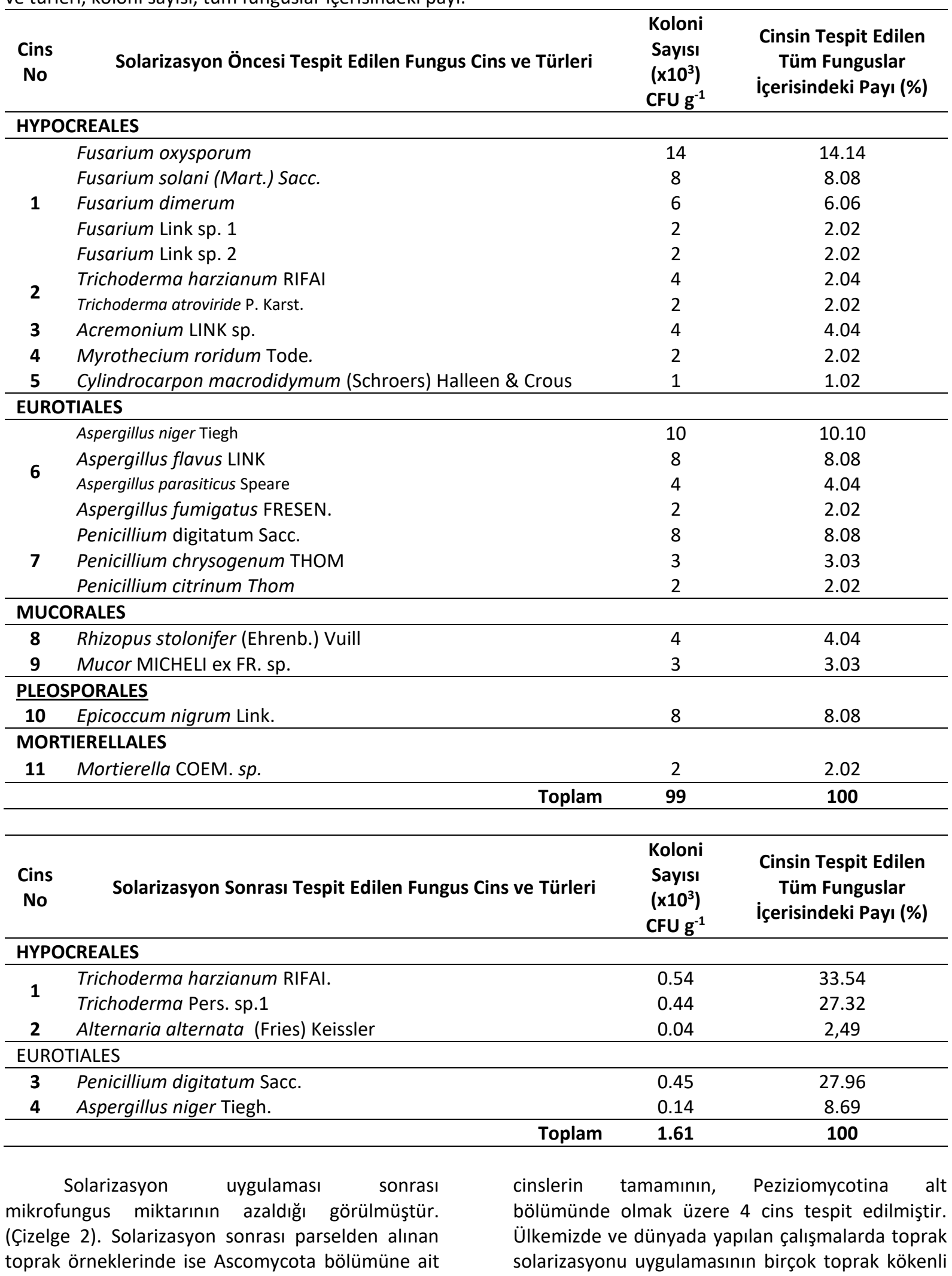


fungal hastalıklara karşı mücadelede başarılı sonuçlar alındığı tespit edilmiştir (Benlioglu ve ark., 2005; Summers ve ark., 2010, Yücel ve ark., 2015). Gövde çürüklüğü hastalığı (Sclerotium rolfsii Sacc.) üzerine yapılan çalışmada $38^{\circ} \mathrm{C}$ üzerinde etmenin sklerotlarının canlıı̆̆ında azalma olurken diğer biyolojik ajanlara karşı hassas hale geldiği bildirilmektedir (Gamliel ve Stapleton, 1993).

Toprak örneklerinin kimyasal analiz sonuçları da Çizelge 3'de verilmiştir. Fungusların gelişebilmek için daha çok asit ortamları tercih ettikleri bilinmektedir (Başbülbül ve ark., 2011). Çalışma alanı toprakları ise genel olarak alkali özelliktedir. Bu durumun fungus sayısı ve çeşitliğinin düşük olmasında etkili olduğu düşünülmektedir. Toprak reaksiyonu $(\mathrm{pH})$ toprağın asitlik ve bazlık durumunu ifade etmektedir. Çoğu bitkide olduğu gibi asma fidanları için de toprak pH'nın 6.0-7.0 arasında olması optimum gelişme aralığı için tercih edilmektedir. Toprağın kimyasal yapısı özelliklede toprak $\mathrm{pH}^{\prime} ı$ mikrobiyal aktiviteyi belirlemektedir. Asit koşullarda funguslar, nötr ve alkalin koşullarda bakteriler etkindir. Asmaların en çok ihtiyaç duyduğu besin maddeleri azot, fosfor ve potasyumdur. Eksiklikleri bitkinin gelişimini yavaşlatmakta veya durdurmaktadır (Anonim, 2017). Çalışmada incelenen topraklarda alınabilir Fosfor (ppm) ve Potasyum (ppm) yönünden değerlendirildiğinde tüm toprak örneklerinin yeterli olduğu görülmektedir.

Çizelge 3. Toprak örneklerine ait kimyasal analiz değerleri.

\begin{tabular}{ccccccccccc}
$\begin{array}{c}\text { Örnek } \\
\text { No }\end{array}$ & pH & Tuz* & Kireç* & N* & P++ & K++ & Mn++ & Fe++ & Cu++ & Zn++ \\
\hline $\mathbf{1}$ & 7.71 & 0.007 & 7.88 & 0.09 & 12.24 & 249.9 & 15.03 & 7.78 & 2.52 & 0.41 \\
$\mathbf{2}$ & 7.70 & 0.005 & 7.09 & 0.10 & 10.42 & 208.8 & 11.24 & 6.36 & 1.83 & 0.35 \\
$\mathbf{3}$ & 7.78 & 0.006 & 7.88 & 0.08 & 11.58 & 220.0 & 12.13 & 6.24 & 2.62 & 1.00 \\
$\mathbf{4}$ & 7.77 & 0.007 & 7.49 & 0.09 & 12.92 & 242.2 & 12.63 & 7.52 & 2.27 & 0.17 \\
$\mathbf{5}$ & 7.79 & 0.008 & 7.88 & 0.09 & 16.24 & 259.0 & 11.47 & 5.99 & 2.93 & 0.83 \\
\hline Ort. & 7.75 & 0.007 & 7.64 & 0.09 & 12.68 & 235.98 & 12.50 & 6.78 & 2.43 & 0.55 \\
\hline
\end{tabular}

* \%; N-Azot, ++ ppm; P-Fosfor, K-Potasyum, Na-Sodyum, Fe-Demir, Cu-Bakır, Zn-Çinko, Mn-Mangan

\section{DNA Izolasyonu ve PCR amplifikasyonları}

İzole edilen fungusların besi ortamında oluşturdukları kolonilerin ve üreme yapıları ya da brimlerinin morfolojik/mikroskopik özelliklerine dayanan teşhis çalışmalarında birçok izolatın tür seviyesinde teşhis edilmesi mümkün olmamaktadır (Oskay ve Şimşek, 2017). Morfolojik tanıya dayalı çalışmalarda özellikle tür seviyesindeki teşhislerin güvenilir olmadığı yönündeki kaygılar yaygındır.

2014 yılında solarizasyon öncesi alınan toprak örneklerinden yapılan izolasyonlar ve morfolojik tanılamalar sonrası Cylindrocarpon, Myrothecium, Fusarium ve Trichoderma cinsleri elde edilmiştir. Asma fidanlığı toprağı için önemli görülen bu cinsler için moleküler tanılama yöntemi kullanılmıştır. Cenis (1992) yöntemine göre yapılan DNA ekstraksiyonu sonrası Multiscan GO $\mu$-drop plate (Thermo Scientific, ABD) ile Fusarium için saptanan DNA miktarı $165.5 \mathrm{ng} / \mu \mathrm{l}$, Cylindrocarpon için $173.9 \mathrm{ng} / \mu \mathrm{l}$, Myrothecium $110.3 \mathrm{ng} / \mu \mathrm{l}$ ve Trichoderma izolatı için $145.3 \mathrm{ng} / \mu \mathrm{l}$ olarak belirlenmiştir. Cenis (1992) rapor ettiği bu ekstraksiyon yöntemiyle yaklaşık 300-600 ng fungal DNA elde edileceğini ve bu yöntemi kullanarak Fusariun oxysporum f.sp. lycopersici, F.o. f.sp. radicis-lycopersici, Rhizoctonia solani AG 1 and AG 3' den elde etmiş olduğu DNA örnekleri ile başarılı bir PCR amplifikasyonu sağladığını bildirmiştir. Benzer şekilde AbdElsalam ve ark. (2003) Cenis'in ekstraksiyon yöntemi ile Fusarium türlerinden 400-
600 ng arasında değişen kalitede ve oldukça saf DNA elde edildiğini bildirmiştir.

Yüksek kalite ve konsantrasyonda DNA bu çalışmada kullanılan ekstraksiyon yöntem ile ekstrakte edilmiştir. PCR ürünlerinin (ITS4/ITS5 genel primer parçaları tarafından güçlendirilmiş) dizilenmesi sonrası gen bankası veri tabanından yararlanılarak (NCBI) BLASTn analizleri ve sonuçları Çizelge 3'de verilmiştir. Cylindirocarpon macrodidymum, Myrothecium roridum, Fusarium solani ve Trichoderma harzianum türleri gen bankası veri tabanı karşılaştırması sonucu elde edilmiştir. Toprak kaynaklı patojenlerin tanılamasında, sekans analizleri öncesi ITS4/ITS5 genel primer çifti ile ilk moleküler tanılamalarını gerçekleştirmek mümkün olabilir. Bu türlerin DNA sekansları NCBI gen bankası verilerinde daha önceden depo edilmiş sekansları ile \%98-100 max. benzerlik göstermiştir.

Fang ve ark. (2011) Batı Avustralya'da yapılan sürvey çalışmaları sonucunda hastalıklı çilek bitkilerinin kök ve taçlarından yaptıkları izolasyonlarda bazı fungusları izole etmişlerdir. Evrensel ITS1 ve ITS4 primerleri kullanılarak, tüm Fusarium spp. 117 izolatlarının ve diğer patojen olan izolatların rDNA gen bölgelerinin PCR ile amplifikasyonu yapılmıştır. Daha sonra sekans sonuçları Gen bankasında BLAST analizi yapılarak benzerlikler bulunmuştur. Hem morfolojik hem de moleküler tanılamalarla kök ve taç çürüklüğü 
hastalığına neden olan fungal etmenlerin F.oxysporum, Rhizoctonia spp. (AG-A, AG-C, AG-I, $A G-K$ ve diğerleri), Cylindrocarpon destructans,
Phoma exigua, Gnomonia fructicola, Phytophthora cactorum, Pythium ultimum ve Macrophomina phaseolina olduğunu ifade etmişlerdir.

Çizelge 4. Solarizasyon öncesi izole edilen funguslardan ITS 4/ITS 5 primerleri ile gerçekleştirilen sekansların blastn analiz sonuçları.

\begin{tabular}{lccccc}
\hline \multicolumn{1}{c}{ Türler } & İzolat & Bölgesi & $\begin{array}{c}\text { Sorgulama } \\
\text { uzunluğu (bp) }\end{array}$ & $\begin{array}{c}\text { GenBank } \\
\text { Erişim No }\end{array}$ & Maksimum Benzerlik (\%) \\
\hline $\begin{array}{l}\text { Cylindirocarpon } \\
\text { macrodidymum }\end{array}$ & MBAE311T & Manisa & 451 & KC989073 & 99 \\
\hline $\begin{array}{l}\text { Myrothecium } \\
\text { roridum }\end{array}$ & MBAE242T & Manisa & 583 & KJ018794 & 98 \\
\hline \begin{tabular}{l} 
Fusarium solani \\
\hline $\begin{array}{l}\text { Trichoderma } \\
\text { harzianum }\end{array}$
\end{tabular} & MBAE231T & Manisa & 641 & JQ245975 & 99 \\
\hline
\end{tabular}

\section{Sonuç ve Öneriler}

Sonuç olarak, çalışmanın yapıldığı asma fidanı üretim parselinde solarizasyon uygulaması öncesi ve sonrası toprak mikrofunguslarının yoğunluğunda önemli farklılık olduğu tespit edilmiştir. Orman, mera gibi alanlara göre daha az mikrofungal koloni birliği bulunduğu görülen fidanlık parselinde, solarizasyon uygulamasından sonra bu mevcudun daha da azaldığı belirlenmiştir. Tarımsal faaliyetlerin (toprak işleme, gübreleme, sulama, pestisit kullanımı vb.) mikrofungal yoğunluk üzerine olumsuz etkisinin bulunduğu bilinmektedir.

Çalışmada Patojen mikrofungusların tanılanmasında moleküler tanılama yöntemi hızlı ve güvenilir sonuç vermiştir.

Karantina etmeni patajenlerle bulaşık fidanlıklarda solarizasyon uygulamasının elverişli olduğu görülmüştür. Solarizasyon uygulamaları sonrasında toprakta azalan biyolojik mücadele ajanlarının (Trichoderma harzianum vb.) toprağa yeniden kazandırılması yönünde çalışmalar yapılması önerilebilir.

\section{Kaynaklar}

Anonim, 2016. Meyve ve Asma Fidanı ile Üretim Materyallerinde Bitki Sağlığı Standartları Talimatı. (http://www.fuab.org.tr) (Erişim tarihi: 12.06.2017).

Anonim, 2017. Bitki ve Toprak Analizleri Ders Notları. Sakarya Üniversitesi. (http://content.Ims.sabis.sakarya.edu.tr) (Erişim tarihi:12.06.2017).

AbdElsalam, K.A., Aly I.N., Abdel-Satar M.A., Khalil M.S., Verreet J.A. 2003. PCR identification of Fusarium genus based on nuclear ribosomalDNA sequence data. African Journal of Biotechnology, 2(4): 82-85.

Azaz, A.D. ve Hasenekoğlu, İ. 1997. An investigation into the microfungal flora of field soils in the GAP (Southeastern Anatolia Project) irrigation area of Harran plain. Tr. J.of Botany, 21: 165-172.

Azaz, A.D. ve Pekel, O. 2002. Comparison of Soil Fungi Flora in Burnt and Unburnt Forest Soils in The Vicinity of Kargicak (Alanya-Turkey). Turk J Bot 26: 409-416.

Başbülbül, G., Bıyık, H., Kalyoncu, F., Kalmış, E., Oryaşin, E. 2011. Aydın, İzmir ve Manisa illerinde endüstriyel atıksular ile kirlenmiş toprakların mikrofungus florasının belirlenmesi. Ekoloji., 20: 66-73.

Benlioglu, S., Boz, O., Yildiz, A., Kaskavalci, G., Benlioglu, K. 2005. Alternative soil solarization treatments for the control of soil-borne diseases and weeds of strawberry in the Western Anatolia of Turkey. Journal of Phytopathology 153: 423-430.

Ben-Yelphet, Y., Shtienberg, D. 1995. Effects of solar radiation and temperature on fusarium wilt in carnation. Phytopathology. 84: 14161421.

Burgess, L.W., Summerell, B.A., Bullock, S., Gott, K., Backhause, D. 1994. Laboratory Manual for Fusarium Research. 3th Edition, Sidney.

Cenis, J.L. 1992. Rapid extraction of fungal DNA for PCR amplification. Nucleic acid Research, 20(9): 2380.

Christensen, M. 1981. Species Diversity and Dominancen Fungal Communities, 201-202, Teh Fungal Community, 1ts Organisation and Rolen The Ecosisytem, Edited By Wicklow, D., And Carroll, G., Marcel Dekker, _nc.,Newyork.

Christensen, M., Frisvad, J.C., Tuthıll, D.E. 2000. Pennicillium Species Diversity in Soil and Same Taxonomik and Ecologycal Notes, 309320. In Integration of Modern Taksonomic Methods for Penicllium and Aspergillus Clasification, Edited By Samson, R.A. And Pitt,J., Harwood Academic Publishers, Singapore. 
Çı̆̆, A. ve Yılmaz, H. 2004. Bazı orkide türlerinde farklı yöntemlerle izole edilen funguslar. Turkish J. Agric. Res. 1: 24-28 TÜTAD ISSN: 2148-2306. http://C:/Users/nurdanpc/Downloads/14-167-2-PB.pdf (Erişim Tarihi: 12.11.2017).

Elad, Y. ve Baker, R. 1985. The role of competition for iron and carbon in suppression of chlamydospore germination of Fusarium spp. by Pseudomonas spp. Phytopathology 75: 1053- 1059.

Fang, X.L., Phillips, D., Li, H., Sivasithamparam, K., Barbetti, M.J. 2011. Comparisons of virulence of pathogens associated with crown and root diseases of strawberry in Western Australia with special reference to the effect of temperature. Scientia Horticulturae, 131: 39-48.

Fidan, Y. ve Yavaş, ì. 1987. Yeni Bağcılığa Geçiş. A.Ü. Ziraat Fak., Ankara.

Gamliel ve A., Stapleton, J.J. 1993. Effect of soil amendment with chicken compost or ammonium phosphate and solarization on pathogen control, rhizosphere microorganisms and lettuce growth. Plant Dis. 77: 886-891.

Garbeva, P., Van Veen, J.V., Van Elsas, J.D. 2004. Microbial Diversity In Soil: Selection Of Microbial Populations By Plant and Soil Type and Implications For Disease Suppressiveness. Annu. Rev. Phytopathol. 42: 243-70.

Halleen, F., Fourie, P.H., Crous, W.C. 2006. A review of black foot disease of grapevines. Phytopathol. Mediterr. 45: 55-S67.

Hasenekoğlu, i. 1982. Erzurum et kombinası civarındaki kirlenmiş toprakların mikrofungus populasyonu. Atatürk Üniversitesi, Fen Fakültesi Dergisi, Özel Sayı, 1(1): 409-416.

Hasenekoğlu, i. ve Azaz, A.D. 1991. Sarıkamış Civarındaki tıraşlanmış orman alanları topraklarının mikrofungus florası ve bunun normal orman toprakları florası ile karşılaştırılması üzerine bir araştırma. Turkish J. of Bot., 15: 214-226.

Kalyoncu, F. ve Özer, A. 2017. Tarım Alanlarından izole edilen mikrofungusların benomil duyarlılıklarının belirlenmesi. Türk Tarım, Gıda Bilim ve Teknoloji Dergisi, 5(10): 11841188.

Kara, Ö. 2002. Kuzey Trakya Dağlık Yetişme Ortamı Bölgesinde Kayın, Meşe, Karaçam Ormanlarındaki Toprak Mikrofunguslarının Mevsimsel Dağılımı, İstanbul Üniversitesi Fen Bilimleri Enstitüsü Orman Mühendisliği A.B.D. Doktora Tezi. İstanbul.
Katan, J., Fishler, G., Grinsten, J. 1983. Short- and long-term effects of soil solarization and crop sequence on Fusarium wilt and yield of cotton in Israel. Phytopathology, 73(8): 1215-1219.

Katan, J. ve DeVay, J.E. 1991. Soil solarization. CRC Press, Boca Raton, Fla.

Kirk, P.M., Cannon, P.F., David, J.C., Stalpers, J.A., 2001. Ainsworth \& Bisby's dictionary of the fungi. 9th edition. CABI Publishing, Wallingford.

Kiss, L. 2003. A Review of Fungal Antagonists of Powdery Mildews and Their Potential as Biocontrol. Pest Management Science, 59: 475-483.

Klich, M.A. 2002. Biogeography of Aspergillus Species in Soil and Litter. Mycologia, 94(4): 21-27.

Leslie, F.J., Pearson, C.A.S., Nelsn, P.E., Toussoun, T.A. 1990. Fusarium spp. from corn, sorghum and soybean fields in the Central and Eastern United States. Phytopathology. 80: 343-350.

Marais, P.G. 1979. Fungi associated with root in vineyards in the Western Cape. Phytophylactica 11: 65-68.

Oskay, F. ve Şimşek, Z. 2017. Çankırı (Eldivan) Karaçam orman topraklarında saptanan mikrofunguslar. Anadolu Orman Araştırmaları Dergisi, 3(1): 23-38.

Petit, E. ve Gubler, W.D., 2006. "Influence of Glomus intraradices on black foot disease caused by Cylindrocarpon macrodidymum on Vitis rupestris under controlled conditions", Plant Dis., 90: 1481-1484.

Pitt, J.I. 2000. A Laboratory Guide to Common Penicillium Species. Food Science Australia.

Rai, R.V. ve Mamatha, T. 2005. Seedling diseases of Some Important Forest Tree Species and Their Management. Working Papers of the Finnish Forest Research Institute 11. http://www.metla.fi/julkaisut/workingpape rs/2005/mwp011.htm (Erişim tarihi: 16.11.2016).

Samson, R.A., Hoekstra, E.S., Frisvad, J.C. 2004. Introduction to Food and Airborne Fungi. CBS Publication, Holland. ISBN: 9789070351427.

Savaş, Y., Çobanoğlu, F., Karabat, S. 2013. Asma Fidanı üretiminin teknik ve ekonomik yönden mevcut durumu. 8. Bağcılık ve Teknolojileri Sempozyumu, 25-28 Eylül, Konya.

Savaş, G.N. ve Yıldız, F. 2015. Control of Alternaria Spp. on Sultanina Seedless Grape Vineyards in Aegean Region. African Journal of Agricultural Science and Technology. 3(12): 527-531. 
Stapleton, J.J. ve DeVay, J.E. 1986. Soil solarization: and nonchemical method for management of plant pathogen and pests; Crop Prot., 5: 190.

Summers, C.G., Newton, A.S., Mitchell, J.P., Stapleton, J.J. 2010. Population dynamics of arthropods associated with early-season tomato plants as influenced by soil surface microenvironment. Crop Protect. 29: 249254.

Úrbez-Torres, J.R., Leavitt, G.M., Voegel, T.M., Gubler, W.D. 2006. Identification and distribution of Botryosphaeria species associated with grapevine cankers in California. Plant Dis 90: 1490-1503.

Quezado, D.A.M., Henz, G.P., Paz-Lima, M.L., Medeiros, A.R., Miranda, B.E.C., Pfenning, L.H., Reis, A. 2010. New hosts of Myrothecium spp. In Brazil and a preliminary in vitro assay of fungicides. Braz. J. Microbiol. 41: 246-252.

Vega, F. E., Posada, F., Aime, M.C, Pava-Ripoll, M., Infante, F., Rehner, S.A. 2008. Entomopathogenic fungal endophytes. Biol. Contr., 46: 72-82.

Waksmann, S.A. 1922. A method for counting the number of fungi in the soil. Nature, Journal of Bacteriology., 7: 339-341.

White, T.J., Bruns, T., Lee, S., Taylor, J. 1990. Amplification and Direct Esquencing of Fungal Ribosamal RNA Genes for Phylogenetics. In: Innis MA, Gelfand DH, Snisky JJ, White TJ, eds. PCR Protocols: A Guide to Methods and Applications. San Dieogo: Academic Press. 315-322.

Yücel, S., Özarslandan, A., Can, C. 2015. Örtü Altı Sebze ve Çilek Yetiştiriciliğinde Toprak Dezenfeksiyonu Uygulamaları. Harran Tarım ve Gıda Bilimleri Dergisi 19(3): 144-150. 